\title{
SAWDUST FOR TREATMENT OF STORMWATER - TEST ON SYNTHETIC STORMWATER CONTAMINATED WITH HEAVY METALS
}

Henric Svensson
Linnaeus University
Audrey Forest
Ecole Nationale du Génie de l'Eau et de l'Environnement, France ${ }^{1}$

Marion Geoffre

Ecole Nationale du Génie de l'Eau et de l'Environnement, France

Marcia Marques

Linnaeus University/Rio de Janeiro State University

William Hogland

Linnaeus University

\begin{abstract}
Stormwater from urban, industrial and rural areas is very often discharged into recipient water bodies without any treatment. This is now changing in many parts of the word, especially in Europe due to The EU Water Framework Directive (European Union, 2000). According to the new policy, will probably stormwater that has often small concentrations but complex mix of different organic and inorganic pollutants has to be treated. Many different systems have been used, such as wetlands and soil infiltration trenches, among others. Sawdust has many times been reported as a good sorbent used for removing mostly toxic metals from wastewaters. However, in most cases, studies have been carried out with distilled water spiked with, for instance, 1-2 different toxic metals. Very few studies have used real wastewater and even less have studied removal of metals from stormwater using sorbent such as sawdust. Sawdust has also drawbacks, since it may release potentially hazardous substances as tannins \& lignin, phenolic compounds, resin acids and overall high COD concentrations which results in oxygen depletion in the recipient water bodies. In this paper, the results of using sawdust as sorbent for removal of heavy metal from stormwater with different pollutants are presented.
\end{abstract}

\section{INTRODUCTION}

Until recently stormwater was considered relatively clean compared to other urban wastewaters. As a consequence, stormwater has been discharged directly into water bodies without any treatment. Municipal wastewater plants are not constructed for treating stormwater, that comes in large volumes particularly after convective summer rains and during the snowmelt, neither adapted for treating pollutants found in the stormwater.

https://doi.org/10.15626/Eco-Tech.2010.033 
In Sweden since the 1970s (William, 1979, Malmqvist and Svensson, 1977) stormwater quantity and quality have been investigated being most of studies focused on urban town district, traffic areas and parking lots. USA has traditionally been in the for front of the research and in 1983 a large project NURP "national urban runoff program" addressed problems and solutions for urban runoff in USA. Later on, in Sweden Marques (2004) studied runoff from different outdoor activities in a modern landfills site including roads, storage, recycling and composting areas. The Swedish Road Administration has implemented a considerable number of pond systems to treat stormwater from highways and large traffic areas $(2006: 115,2006)$.

About 77\% of Sweden is covered by forest (Swedish Forest Agency, 2010), which is one of the nation's most important natural resource that is exploited in different ways. According to Swedish Federation of Wood and Furniture Industry (http://www.tmf.se, 2010) it exist about 800 wood processing and furniture industries in Sweden. This industrial branch produces wood residues in different forms such as sawdust and wood chips that have a potential to be used to clean stormwater contaminated with heavy metals. Many reports describe sawdust and wood chips as a potential metal absorbent to treat wastewater (see Table 2). However, almost none is working with stormwater and the challenges and opportunities connected to stormwater treatment. Stormwater is often characterized by many metals of relatively low concentrations and varying $\mathrm{pH}$.

The present study investigated if sawdust can be used in the treatment of stormwater contaminated with the heavy metals such as $\mathrm{Zn}, \mathrm{Cu}, \mathrm{Cd}, \mathrm{Pb}$, at the same $\mathrm{pH}$ normally found in the stormwater net. The study was based on two different approaches: (1) the wood residues that are present in the stormwater net were analysed in order to investigate if the material contains metals and if metals are preserved in the sorbent in the natural environment; (2) a column was constructed and filled with sawdust to study under laboratory conditions the sorption of metals using a spiked solution that contained the above-mentioned metals.

The objective was to investigate if the wood waste found at wood industries, could be used as adsorbent to treat the stormwater generated on site.

\section{BACKGROUND}

This study is a part of a larger research project called "Development of an Integrated Approach for Industrial Wastewater \& Stormwater Management in the Wood-Industry Sector" carried out at Linnaeus University and sponsored by the KK-foundation and a number of companies, including one wood-laminate floor producer, one energy producer based on wood waste and two suppliers of chemicals regularly used to produce wood-laminate floors and wood furniture. The research is focused on the development of an innovative approach for local, as much as possible low cost and easy-to manage treatment of the wastewater and the stormwater generated by wood-based industries with emphasis Eco-technologies.

\section{MATERIALS AND METHODS}

The material used in this investigation was collected at the wood industry AB Gustaf Kähr (Kährs) in Nybro, Sweden. The material was found at the storage area for logs and wooden planks. Sawdust was collected from the impervious surfaces and from the gully pots that form the stormwater net. The material was randomly collected and classified according its collection place and its visual degradation status. A sampling method for each type of the four wood residues was selected. 
Virgin woodchips: This material is classified as residues that just came out of the floor production machine and was used as a reference zero value, since it has not been in contact with the precipitation or the stormwater runoff. Three different wood species were selected (oak, pine, and maple), since they are frequently found in the manufacturing process of the industry.

Non-degraded woodchips: This material had been produced recently, but it had already been affected by precipitation, but not enough to begin a significant biodegradation process. The spaces around heaps with woodchips were chosen for sampling. After chosen the places for collection, a systematic sampling method was chosen. Sampling consisted of picking up one shovel of woodchips every 2 meters, on a path describing a circle around the woodchip pile.

Degraded woodchips: This material was usually blackish, because of the advanced biodegradation it had suffered already at the moment it was collected. It was mainly located nearby the gully pots and was sampled as described above.

Sediments in gully pots: This material located in the gully pot was usually the most degraded one. Sub-samples were taken from each gully pots that could be opened and then, the subsamples were mixed to form one composite sample

This procedure was used with the purpose of assessing how degradation affects the adsorption capacity and how the metals are distributed in materials with different degree of degradation. Each one of the four classes of wood residues were then analysed for metals with batch leaching extraction techniques with booth deionization water and EDTA solution of 5M. Metals quantification with acid digestion was carried out by the accredited laboratory Eurofin in Sweden.

\section{Column leaching test}

According to (Nehrenheim, 2007), column experiments can be considered to yield more reliable data for future on-site applications than batch tests and therefore were column test chosen. A system with up-flow columns of $2.3 \mathrm{~L}$ was filled with wood sawdust of pine (Pinus sylvestris) according to the Figure 1 . The amount of sorbent used for filling the columns was $300 \mathrm{~g}$ of dry matter. The up flows through the column were established to be $2 \mathrm{~L} / \mathrm{min}$ and void space were about $0.95 \mathrm{~L}$ which gives a retention time of about $30 \mathrm{~min}$. In total, $288 \mathrm{~L}$ of synthetic stormwater crossed the column. The synthetic stormwater was produced based on earlier studies of stormwater concentrations at Kährs (personal information by Fabio Kazcala). Four of the most important metals were used in this study: $\mathrm{Cu}, \mathrm{Pb}, \mathrm{Zn}, \mathrm{Cd}$ in the concentrations shown in Table 1.

Table 1: Concentrations of metals in the synthetic stormwater used in the tests.

\begin{tabular}{cc}
\hline Compound in the synthetic stormwater & Concentration $(\mu \mathrm{g} / \mathrm{L})$ \\
\hline $\mathrm{Cu}$ & 240 \\
\hline $\mathrm{Pb}$ & 33 \\
\hline $\mathrm{Zn}$ & 510 \\
\hline $\mathrm{Cd}$ & 33 \\
\hline \hline
\end{tabular}




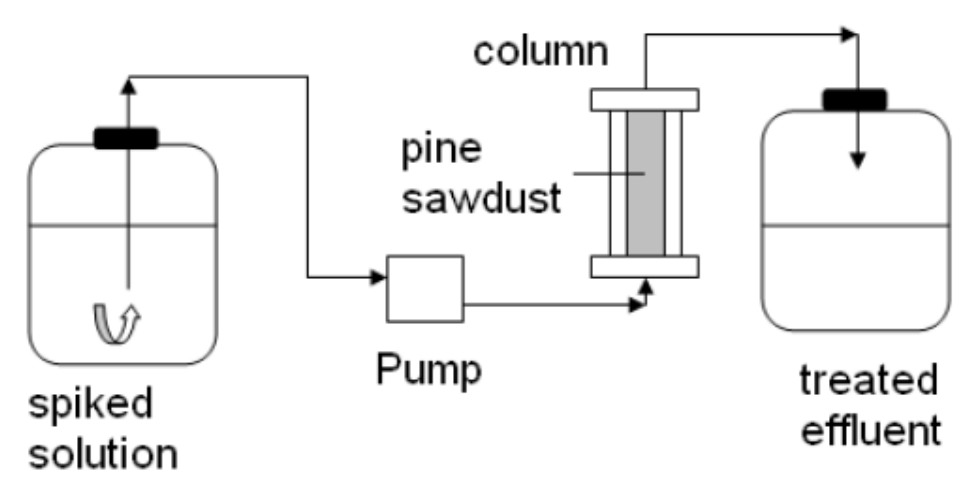

Figure 1. Laboratory set up for column tests.

Sawdust of Scots Pine (Pinus sylvestris) was chosen because it is the one of the most common wood species used in Swedish wood manufacturing industries. Samples of the sawdust were sent to accredited laboratory Eurofins.

\section{RESULTS AND DISCUSSION}

The total amount of metals found in the wooden material (sawdust of Pinus sylvestris) is presented in Table 2.

Table 2. Amount of metals found in pine sawdust.

\begin{tabular}{|c|c|}
\hline Metal & $\begin{array}{c}\text { Content } \\
\text { (mg per kg of dry matter) }\end{array}$ \\
\hline $\mathrm{Cu}$ & 0.93 \\
\hline $\mathrm{Pb}$ & $<0,074$ \\
\hline $\mathrm{Zn}$ & 11.0 \\
\hline $\mathrm{Cd}$ & 0.2 \\
\hline $\mathrm{Ba}$ & 4.6 \\
\hline $\mathrm{Co}$ & $<0,074$ \\
\hline $\mathrm{Cr}$ & 0.19 \\
\hline
\end{tabular}

The amounts of metals extracted from wood residues at different stages of degradation are shown in Figure 2.

The results in Figure 2 confirm that the wood residues have the capacity for adsorbing metals and once metals are captured by the wood residues they are not easily released. The different results between the water test and the EDTA solution test shows that the metals is hardly bound to the sawdust and it is necessary powerful ligands to extract them from the adsorbent. When looking at the degradation effect on the wood residues it is important to be highlight that more degraded material means also longer time exposed outdoors and therefore, more contact time has passed and more amount of metals has been bound. However, according to Figure 2, the results hardly indicate that degradation reduces significantly the absorption capacity. This means that if filter is installed for long-time period the degradation process will probably not release the captured metals. 
According to the results in Figure 3, pine sawdust presents considerable differences in the sorption capacity for different metals. Cd seems to be sorbed until the competition from the other metals gets too high; after that, release of $\mathrm{Cd}$ from the sawdust is suggested. For $\mathrm{Cu}$ and $\mathrm{Pb}$ the reduction even after percolation of $1 \mathrm{~m}^{3}$ water $/ \mathrm{kg}$ sawdust is still higher than $50 \%$. In the case $\mathrm{Zn}$, for instance, the reduction after $49 \mathrm{~h}\left(0.16 \mathrm{~m}^{3}\right.$ water/ $\mathrm{kg}$ sawdust $)$ is already below $50 \%$. This effect on sorption of $\mathrm{Zn}$ could be connected with the fact that the $\mathrm{pH}$ dropped below 3.5 but also with the fact that absorption sites available for $\mathrm{Zn}$ might be filled.

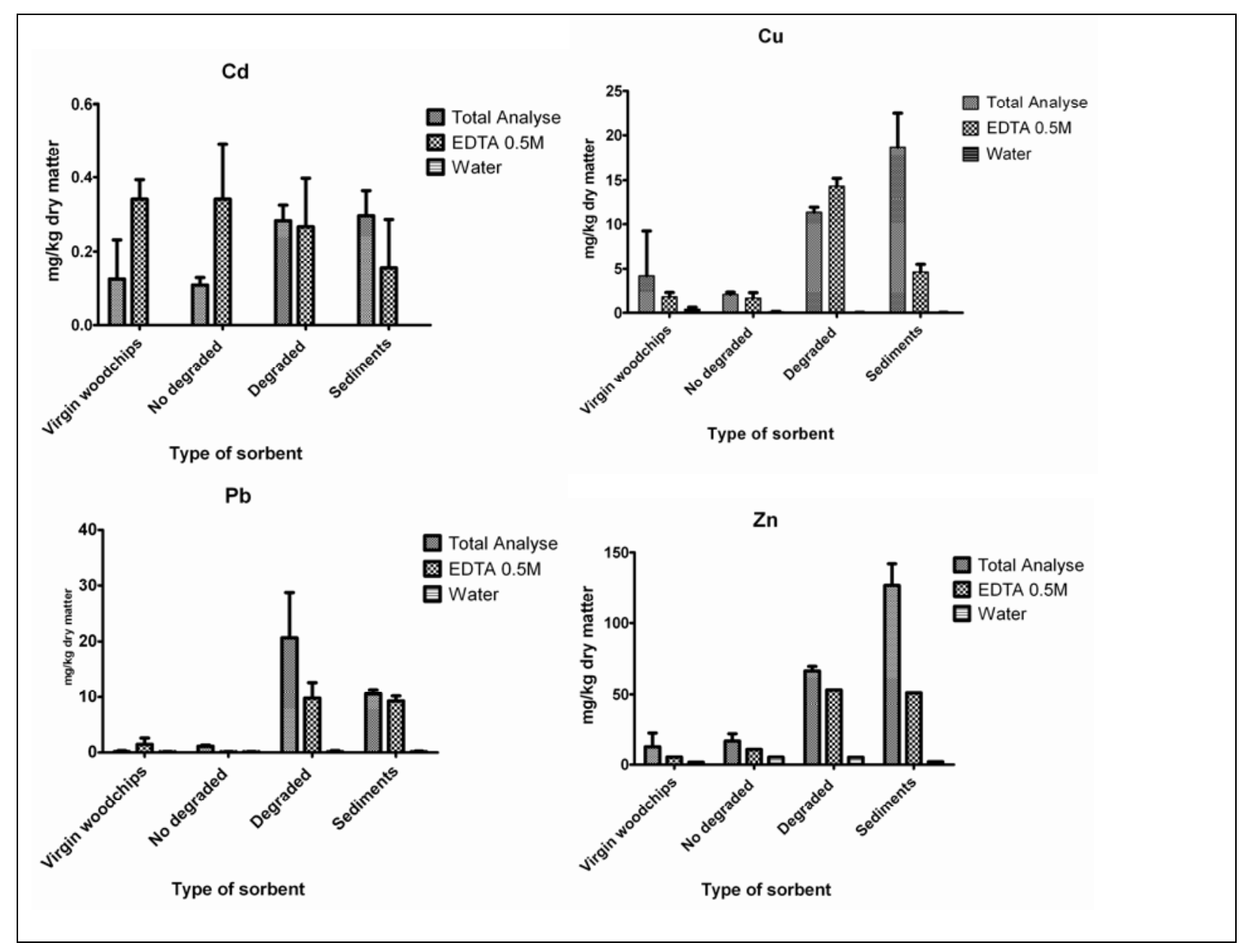

Figure 2: Amount of metals extracted from different types of sorbent with different techniques.

\section{Column leaching test}

Contact time: The retention time through the column were approximately $30 \mathrm{~min}$, which is lower than most of the batch tests reported (Genc-Fuhrman et al., 2007, Ajmal et al., 1996, Shin et al., 2007) where the contact time can be longer than $4 \mathrm{~h}$. This contact time could be one reason that it doesn't work that good but in other hand, stormwater runoff is often generated when convective precipitation occurs and it is likely that even a higher flow than the one tested will apply.

Table 2 shows a number of publications that address the sorption capacity of wood sawdust and metals removal from the water phase. 
Linnaeus ECO-TECH '10

Kalmar, Sweden, November 22-24, 2010

\section{Column test}

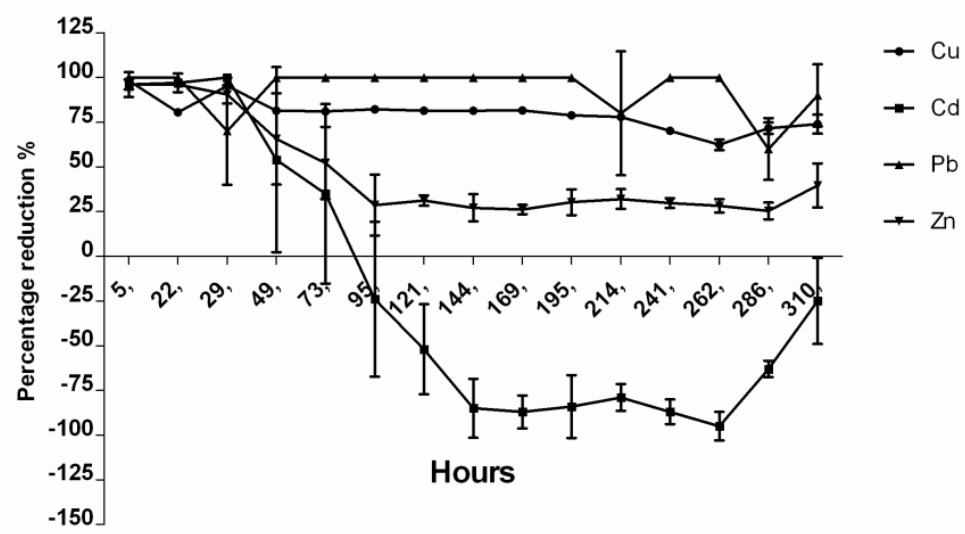

Figure 3: Reduction (in \%) of metals $\mathrm{Cu}, \mathrm{Cd}, \mathrm{Pb}$ and $\mathrm{Zn}$ from the water phase over time in columns using pine sawdust as sorbent.

Table 2. Publications addressing toxic metal absorption by wood residues.

\begin{tabular}{|c|c|c|c|c|c|c|}
\hline Article & Solution & $\begin{array}{c}\text { Material (sawdust, bark, } \\
\text { species) }\end{array}$ & Pre-treated & Kind of metals & $\begin{array}{l}\text { Batch or } \\
\text { Column }\end{array}$ & $\begin{array}{c}\text { Reduction (\%), } \\
\text { or absorption } \\
\text { lelvel }\end{array}$ \\
\hline $\begin{array}{l}\text { (Acar and Eren, } \\
2006)\end{array}$ & Synthetic & $\begin{array}{l}\text { Sawdust of Poplar } \\
\text { (Samsun Clone) }\end{array}$ & $\mathrm{H}_{2} \mathrm{SO}_{4}$ & $\mathrm{Cu}$ & Batch & $92,38 \%$ \\
\hline $\begin{array}{l}\text { (Acemioglu and } \\
\text { Alma, 2004) }\end{array}$ & Synthetic & $\begin{array}{c}\text { Sawdust of pine (Pinus } \\
\text { brutia) }\end{array}$ & No & $\mathrm{Cu}$ & Batch & $81 \%$ \\
\hline $\begin{array}{l}\text { (Ahmad et al., } \\
\text { 2005) }\end{array}$ & wastewater & $\begin{array}{l}\text { Bark of Pine (Pinus } \\
\text { roxburghii) }\end{array}$ & No & $\begin{array}{l}\mathrm{Cr} \text { (VI), } \mathrm{Cu} \text { (II), Ni } \\
\text { (II), Cd (II), Zn (II) }\end{array}$ & Batch & $\begin{array}{c}\mathrm{Cr}>\mathrm{Zn}>\mathrm{Cu}>\mathrm{Ni}> \\
\mathrm{Cd}\end{array}$ \\
\hline $\begin{array}{l}\text { (Ajmal et al., } \\
1996 \text { ) }\end{array}$ & wastewater & $\begin{array}{l}\text { Mango tree (mangifera } \\
\text { indica) sawdust }\end{array}$ & Phosphate & $\mathrm{Cr}$ & Batch & Cr: $100 \%$ \\
\hline $\begin{array}{l}\text { (Ajmal et al., } \\
\text { 1998) }\end{array}$ & wastewater & $\begin{array}{l}\text { Sawdust of Mango tree } \\
\text { (Mangifera indica) }\end{array}$ & $\mathrm{H}_{2} \mathrm{O}$ & $\mathrm{Cu}$ & Batch & $63 \%$ \\
\hline $\begin{array}{l}\text { (Argun et al., } \\
\text { 2007) }\end{array}$ & Synthetic & $\begin{array}{c}\text { Sawdust of Oak (Quercus } \\
\text { coccifera) }\end{array}$ & $\begin{array}{c}\text { Pre-treated with } \\
\mathrm{HCl}\end{array}$ & $\mathrm{Cu}, \mathrm{Ni}, \mathrm{Cr}$ & Batch & $\begin{array}{l}\text { Cu: } 93 \% \\
\text { Cr: } 84 \% \\
\text { Ni: } 82 \%\end{array}$ \\
\hline $\begin{array}{l}\text { (AlAsheh and } \\
\text { Duvnjak, 1997) }\end{array}$ & Synthetic & $\begin{array}{l}\text { Bark, cones and needles } \\
\text { from Pine }\end{array}$ & $\mathrm{H}_{2} \mathrm{O}$ & $\mathrm{Pb}, \mathrm{Cd}, \mathrm{Cu}, \mathrm{Ni}$ & Batch & $\mathrm{Pb}>\mathrm{Cd}>\mathrm{Cu}>\mathrm{Ni}$ \\
\hline $\begin{array}{l}\text { (Garg et al., } \\
2004 \text { ) }\end{array}$ & Synthetic & $\begin{array}{c}\text { Sawdust of Indian } \\
\text { Rosewood (Dalbergia } \\
\text { sissoo) }\end{array}$ & $\begin{array}{l}\text { Formaldehyde } \\
\text { treated sawdust }\end{array}$ & $\mathrm{Cr}$ & Batch & $100 \%$ \\
\hline $\begin{array}{l}\text { (Genc-Fuhrman } \\
\text { et al., 2007) }\end{array}$ & Synthetic & $\begin{array}{l}\text { Bark (Zugol industrial } \\
\text { sorbent) }\end{array}$ & No & $\begin{array}{c}\text { As, } \mathrm{Cd}, \mathrm{Cr}, \mathrm{Cu}, \mathrm{Ni}, \\
\mathrm{Zn} .\end{array}$ & Batch & \\
\hline $\begin{array}{l}\text { (Kaczala et al., } \\
\text { 2009) }\end{array}$ & wastewater & $\begin{array}{c}\text { Sawdust from Pine (Pinus } \\
\text { Sylvestris) }\end{array}$ & No & $\mathrm{Pb}$ and $\mathrm{V}$ & Batch & $\begin{array}{l}\text { Pb: } 99 \% \\
\text { V: } 95 \%\end{array}$ \\
\hline (Shin et al., 2007) & Synthetic & $\begin{array}{c}\text { Juniper Bark and Juniper } \\
\text { sawdust }\end{array}$ & No & $\mathrm{Cd}$ & Batch & \\
\hline (Seki et al., 1997) & Synthetic & $\begin{array}{l}15 \text { different coniferous } \\
\text { barks }\end{array}$ & $\begin{array}{l}\mathrm{NaOH} \text { and } \\
\text { ethanol- } \\
\text { benzene }\end{array}$ & $\begin{array}{c}\mathrm{Cd}, \mathrm{Cu}, \mathrm{Zn}, \mathrm{Ag}, \mathrm{Co} \\
\mathrm{Mn}, \mathrm{Ni}\end{array}$ & Column & \\
\hline $\begin{array}{l}\text { (Sciban et al., } \\
\text { 2007) }\end{array}$ & wastewater & Poplar wood Sawdust & No & $\mathrm{Cu}, \mathrm{Zn}, \mathrm{Cd}$ & Batch & $\mathrm{Cu}>\mathrm{Zn}>\mathrm{Cd}$ \\
\hline $\begin{array}{l}\text { (Sciban and } \\
\text { Klasnja, 2004) }\end{array}$ & wastewater & $\begin{array}{c}\text { Sawdust from poplar, } \\
\text { Willow, Fir, Oak, Black } \\
\text { locust. }\end{array}$ & No & $\begin{array}{c}\mathrm{Cu}(\mathrm{II}) . \mathrm{Zn}(\mathrm{II}), \mathrm{Ni}(\mathrm{II}), \\
\mathrm{Cd}(\mathrm{II})\end{array}$ & Batch & $\mathrm{Cu}>\mathrm{Ni}>\mathrm{Zn}>\mathrm{Cd}$. \\
\hline (Yu et al., 2000) & Synthetic & Maple sawdust & No & $\mathrm{Cu}$ & Batch & $\mathrm{Cu} 1.79 \mathrm{mg} / \mathrm{g}$ \\
\hline (Yu et al., 2001) & Synthetic & Maple sawdust & No & $\mathrm{Cu}$ and $\mathrm{Pb}$ & Batch & $\begin{array}{c}\mathrm{Cu} 1.79 \mathrm{mg} / \mathrm{g} \\
3,19 \mathrm{mg} / \mathrm{g}\end{array}$ \\
\hline
\end{tabular}


The sorption capacity of the sawdust is dependent on a number of factors, such as absorbent dose, size of the sawdust, contact time, temperature, $\mathrm{pH}$, ionic strength of the aqueous solution(Shukla et al., 2002, Argun et al., 2007). Stormwater is often characterized by having low concentrations of many different pollutants and trace metals which limits the efficiency of absorbents such as sawdust. When using the databases Web of Science and BIOSIS Previews 16 articles were found (see Table 2). None of these articles focused on stormwater. Seven of the above-mentioned articles only working with one metal, which prevents these investigations of finding the phenomena observed in Figure 3, where the $\mathrm{Cd}$ is released after a while.

This study has shown that $300 \mathrm{~g}$ pine sawdust is able to clean $98 \mathrm{~L}$ synthetic stormwater to $50 \%$ of trace metals (if $\mathrm{Cd}$ is not considered). For industries like Kährs that generates about $75000 \mathrm{~m}^{3}$ stormwater annually at the wood storage area, the amount of sawdust required should be about $230000 \mathrm{~kg} /$ year.

Stormwater treatment using sawdust for removal of polycyclic aromatic hydrocarbons has been reported (Boving and Neary, 2007, Cambiella et al., 2006) but no publication was found reporting metal reduction in stormwater made by sorption to sawdust.

\section{Effects of wood residual}

Leaching of organic substances from wood residues that have the potential to be toxic, such as phenols, tannins and lignin, resin acids, terpenes has been described and for some wood species, a low $\mathrm{pH}$ in the leachate have been found (Hedmark and Scholz, 2008, Tao et al., 2005, Rupar and Sanati, 2005). COD is a proxy indicator that indirectly quantifies the amount of chemically oxidizing substances in the water phase. The main problem with leachate from wood industries is that high COD can create oxygen depletion in water courses, additionally to eventual toxic effects (Hedmark and Scholz, 2008). This means that a trade off between the sorption capacity and the pollutants release must be considered. Unpublished results from leaching tests (Svensson, 2010) show that $1 \mathrm{~kg}$ of dry pine sawdust could release $60 \mathrm{~g}$ of COD when washed a number of times. This means that the filter itself could release about 13 ton of COD to the water phase which depending on the characteristics of the recipient water body, could eventually causes more environmental problems than the trace metals.

This high amount of organic pollutants probably do not leach from other common biosorbents, such as pet, algae and activated carbon (Argun et al., 2007, Gode et al., 2008). Due to the special defence mechanisms found in trees, Due to the fact that trees have a long life time and during its life they have to defend themselves from different threats, they developed defence metabolites (Franceschi et al., 2005, Witzell and Martin, 2008). Such strategy is not common in organisms with shorter life time such as peat and algae.

\section{CONCLUSIONS}

Sawdust has the capacity of adsorbing heavy metals and hydrocarbons. However, in order to use sawdust or other wood residues for treating stormwater some constraints must be taken into account. The absorption capacity depends on the contaminant's original concentration in the water phase, which in the case of stormwater is often very low, although stormwater can be generated in high volumes. The other problem is the high amounts of organic pollutants usually released from the wood residues, which can easy become an environmental problem to the recipient water body due to their toxicity. Wood residues pre-treatment is often reported as an attempt to improve the sorption capacity (Acar and Eren, 2006, Ajmal et al., 1996) and 
these pre-treatments usually increase the removal efficiency. However, is it feasible to pretreat wood residues in the amounts required for a stormwater filter? Will it still be economically attractive or environmentally sound sorbent if pre-treatment is carried out using, for instance, $\mathrm{NaOH}$ solution, ethanol-benzene or formaldehyde? These are some questions that must be answered before recommending the use of sawdust in field scale.

\section{REFERENCES}

2006:115, V. P. 2006. Dagvattendammar - Om provtagning, avskiljning och dammhydraulik. Dagvattendammar - Om provtagning, avskiljning och dammhydraulik.

ACAR, F. N. \& EREN, Z. 2006. Removal of Cu(II) ions by activated poplar sawdust (Samsun Clone) from aqueous solutions. Journal of Hazardous Materials, 137, 909-914.

ACEMIOGLU, B. \& ALMA, M. H. 2004. Sorption of copper(II) ions by pine sawdust. Holz Als Roh-Und Werkstoff, 62, 268-272.

AHMAD, R., RAO, R. A. K. \& MASOOD, M. M. 2005. Removal and recovery of Cr(VI) from synthetic and industrial wastewater using bark of Pinus roxburghii as an adsorbent. Water Quality Research Journal of Canada, 40, 462-468.

AJMAL, M., MOHAMMAD, A., YOUSUF, R. \& AHMAD, A. 1998. Adsorption behaviour of cadmium, zinc, nickel and lead from aqueous solutions by mangifera indica seed shell. Indian Journal of Environmental Health, 40, 15-26.

AJMAL, M., RAO, R. A. K. \& SIDDIQUI, B. A. 1996. Studies on removal and recovery of $\mathrm{Cr}(\mathrm{VI})$ from electroplating wastes. Water Research, 30, 1478-1482.

ALASHEH, S. \& DUVNJAK, Z. 1997. Sorption of cadmium and other heavy metals by pine bark. Journal of Hazardous Materials, 56, 35-51.

ARGUN, M. E., DURSUN, S., OZDEMIR, C. \& KARATAS, M. 2007. Heavy metal adsorption by modified oak sawdust: Thermodynamics and kinetics. Journal of Hazardous Materials, 141, 77-85.

BOVING, T. B. \& NEARY, K. 2007. Attenuation of polycyclic aromatic hydrocarbons from urban stormwater runoff by wood filters. Journal of Contaminant Hydrology, 91, 4357.

CAMBIElla, A., ORTEA, E., RIOS, G., BENITO, J. M., PAZOS, C. \& COCA, J. 2006. Treatment of oil-in-water emulsions: Performance of a sawdust bed filter. Journal of Hazardous Materials, 131, 195-199.

FRANCESCHI, V. R., KROKENE, P., CHRISTIANSEN, E. \& KREKLING, T. 2005. Anatomical and chemical defenses of conifer bark against bark beetles and other pests. New Phytologist, 167, 353-375.

GARG, V. K., GUPTA, R., KUMAR, R. \& GUPTA, R. K. 2004. Adsorption of chromium from aqueous solution on treated sawdust. Bioresource Technology, 92, 79-81.

GENC-FUHRMAN, H., MIKKELSEN, P. S. \& LEDIN, A. 2007. Simultaneous removal of $\mathrm{As}, \mathrm{Cd}, \mathrm{Cr}, \mathrm{Cu}, \mathrm{Ni}$ and $\mathrm{Zn}$ from stormwater: Experimental comparison of 11 different sorbents. Water Research, 41, 591-602.

GODE, F., ATALAY, E. D. \& PEHLIVAN, E. 2008. Removal of Cr(VI) from aqueous solutions using modified red pine sawdust. Journal of Hazardous Materials, 152, 1201-1207.

HEDMARK, A. \& SCHOLZ, M. 2008. Review of environmental effects and treatment of runoff from storage and handling of wood. Bioresource Technology, 99, 5997-6009.

KACZALA, F., MARQUES, M. \& HOGLAND, W. 2009. Lead and vanadium removal from a real industrial wastewater by gravitational settling/sedimentation and sorption onto Pinus sylvestris sawdust. Bioresource Technology, 100, 235-243. 
MALMQVIST, P. A. \& SVENSSON, G. 1977. Urban storm-water pollution sources. Proceedings of the Amsterdam Symposium - effects of urbanization and industrialization on hydrological regime and on water quality. IAHS-AISH.

NEHRENHEIM, E. 2007. Metal retention from leachate using Industrial Waste Products. Mälardalen University.

RUPAR, K. \& SANATI, M. 2005. The release of terpenes during storage of biomass. Biomass \& Bioenergy, 28, 29-34.

SCIBAN, M. \& KLASNJA, M. 2004. Wood sawdust and wood originate materials as adsorbents for heavy metal ions. Holz Als Roh-Und Werkstoff, 62, 69-73.

SCIBAN, M., RADETIC, B., KEVRESAN, D. \& KLASNJA, M. 2007. Adsorption of heavy metals from electroplating wastewater by wood sawdust. Bioresource Technology, 98, 402-409.

SEKI, K., SAITO, N. \& AOYAMA, M. 1997. Removal of heavy metal ions from solutions by coniferous barks. Wood Science and Technology, 31, 441-447.

SHIN, E. W., KARTHIKEYAN, K. G. \& TSHABALALA, M. A. 2007. Adsorption mechanism of cadmium on juniper bark and wood. Bioresource Technology, 98, 588594.

SHUKLA, A., ZHANG, Y. H., DUBEY, P., MARGRAVE, J. L. \& SHUKLA, S. S. 2002. The role of sawdust in the removal of unwanted materials from water. Journal of Hazardous Materials, 95, 137-152.

SVENSSON, H. 2010. Leaching Test with Sawdust from Different Tree Species Appropriateness of using them as adsorption media in wastewater and in stormwater treatment. Master of science, Linnaeus University.

TAO, W. D., HALL, K. J., MASBOUGH, A., FRANKOWSKI, K. \& DUFF, S. J. B. 2005. Characterization of leachate from a woodwaste file. Water Quality Research Journal of Canada, 40, 476-483.

WILLIAM, H. 1979. Snö och snöhantering I Lund vintern 1978-79. Lund: Institutionen för teknisk vattenresurslär.

WITZELL, J. \& MARTIN, J. A. 2008. Phenolic metabolites in the resistance of northern forest trees to pathogens - past experiences and future prospects. Canadian Journal of Forest Research-Revue Canadienne De Recherche Forestiere, 38, 2711-2727.

YU, B., ZHANG, Y., SHUKLA, A., SHUKLA, S. S. \& DORRIS, K. L. 2000. The removal of heavy metal from aqueous solutions by sawdust adsorption - removal of copper. Journal of Hazardous Materials, 80, 33-42.

YU, B., ZHANG, Y., SHUKLA, A., SHUKLA, S. S. \& DORRIS, K. L. 2001. The removal of heavy metals from aqueous solutions by sawdust adsorption - removal of lead and comparison of its adsorption with copper. Journal of Hazardous Materials, 84, 83-94. 